\title{
Extracellular Nucleotides Differentially Regulate Interleukin-1及 Signaling in Primary Human Astrocytes: Implications for Inflammatory Gene Expression
}

\author{
Gareth R. John, ${ }^{1}$ Julie E. Simpson, ${ }^{3}$ M. Nicola Woodroofe, ${ }^{3}$ Sunhee C. Lee, ${ }^{1}$ and Celia F. Brosnan ${ }^{1,2}$ \\ Departments of ${ }^{1}$ Pathology and ${ }^{2}$ Neuroscience, Albert Einstein College of Medicine, Bronx, New York 10461, and \\ ${ }^{3}$ Division of Biomedical Sciences, Sheffield Hallam University, Sheffield, South Yorkshire S1 1WB, United Kingdom
}

The cytokine interleukin-1 $\beta(\mathrm{IL}-1 \beta)$ is a potent activator of human astrocytes, inducing or modulating expression of multiple proinflammatory genes via activation of the transcription factors nuclear factor- $\kappa \mathrm{B}(\mathrm{NF}-\kappa \mathrm{B})$ and activator protein-1 (AP1). In this study, we examined whether IL-1 $\beta$ signaling is regulated in these cells by extracellular nucleotides that are released at high concentrations under inflammatory conditions and act as ligands for members of the P2 receptor family. Using reporter constructs and electromobility shift assays, we found that cotreatment of astrocyte cultures with ATP $(1-100 \mu \mathrm{M})$ significantly potentiated IL-1 $\beta$-mediated activation of NF- $\kappa \mathrm{B}$ and AP-1 and that ATP alone activated AP-1. These effects were blocked by the P2 receptor antagonists XAMR 0721, periodate-oxidized ATP, and suramin. A role for ATP in modulating IL-1 $\beta$-mediated inflammatory gene expression was supported further by the observation that ATP potentiated the IL-1 $\beta$-induced expression of IL-8 mRNA and protein but strongly downregulated IP-10 expression. Reverse transcription-PCR and cloning demonstrated expression of the ATP-responsive $\mathrm{P} 2$ receptor subtypes $P 2 Y_{1}, P 2 Y_{2}$, and $P 2 X_{7}$, as well as the ATP-insensitive receptor $\mathrm{P}_{2} \mathrm{Y}_{4}$. ADP, a selective agonist for $P 2 Y_{1}$, produced results similar to or greater than those obtained using ATP, whereas 2'-3'-O-(4-benzoylbenzoyl)-ATP, a selective agonist for $\mathrm{P}_{2} \mathrm{X}_{7}$, was less effective than ATP. In contrast, UTP, a selective agonist for $\mathrm{P}_{2} \mathrm{Y}_{2}$ and $\mathrm{P}_{2} \mathrm{Y}_{4}$, was ineffective. These studies indicate that different P2 receptor subtypes play distinct roles in the modulation of IL$1 \beta$-mediated signal transduction in human astrocytes, and that signaling via P2 receptors may fine-tune the transcription of genes involved in inflammatory responses in the human CNS.

Key words: P2 receptors; IL-1 $\beta$; human fetal astrocytes; transcription factors $N F-\kappa B$ and $A P-1$; chemokines; extracellular nucleotides
Astrocytes, oligodendrocytes, and microglia form the major classes of glial cells in the CNS. Astrocytes function to maintain the homeostatic environment of the CNS and also play an important role in immune regulation, acting as a source of chemokines, cytokines, and effector molecules (Ransom and Sontheimer, 1992; Norenberg, 1997). Coordination of function in astrocyte populations is believed to occur via at least two different mechanisms: an intercellular pathway mediated by gap junctions composed of connexin43 subunits and an extracellular pathway mediated by receptors of the $\mathrm{P} 2$ family that respond to nucleotides such as ATP, ADP, UTP, and UDP (Guthrie et al., 1999; John et al., 1999; Scemes et al., 2000). These pathways are thought to provide a mechanism whereby astrocytes are able to sense and respond to changes in the state and activity of neighboring cells and the surrounding CNS microenvironment.

Inflammatory responses in the CNS rapidly induce marked changes in astrocytes that reflect an activated state, usually referred to as a reactive gliosis (Brosnan and Lee, 1997). Previous

\footnotetext{
Received Feb. 13, 2001; revised March 16, 2001; accepted March 19, 2001.

This work was supported by United States Public Health Service Grants NS40137, NS11920 (C.F.B.), and MH55477 (S.C.L.), National Multiple Sclerosis Society Fellowship FG1355 (G.R.J.), Multiple Sclerosis Society of Great Britain and Northern Ireland Grant 0517/U91298 (J.E.S., M.N.W.), and a Boehringer Ingelheim Fond award (J.E.S.). We thank Dr. Karen Weidenheim, Director of the Human Fetal Tissue Repository, for tissue collection. We also thank Wa Shen, Dr. Meng-Liang Zhao, Dr. Eliana Scemes, and Dr. David Spray for their assistance.

Correspondence should be addressed to Dr. Celia F. Brosnan, Department of Pathology, Albert Einstein College of Medicine, 1300 Morris Park Avenue, Bronx, NY 10461. E-mail: brosnan@aecom.yu.edu.

Copyright (C) 2001 Society for Neuroscience $0270-6474 / 01 / 214134-09 \$ 15.00 / 0$
}

work has shown that the cytokine interleukin- $1 \beta$ (IL-1 $\beta)$ is a key activator of primary human astrocytes, inducing or modulating gene expression in a similar pattern to that observed under inflammatory conditions in vivo (Lee et al., 1993; Benveniste et al., 1994). IL-1 $\beta$ activates the transcription factors nuclear factorkappa $\mathrm{B}(\mathrm{NF}-\kappa \mathrm{B})$ and activator protein-1 (AP-1), inducing the expression of multiple genes associated with inflammation, including chemokines, cytokines, enzymes, and adhesion molecules (Davis, 2000; Karin and Delhase, 2000). In the normal healthy CNS, constitutive expression of IL- $1 \beta$ is low and is restricted to specific neuronal tracts (Breder et al., 1988). However, increased IL-1 $\beta$ expression has been extensively documented in vivo in a number of different inflammatory and degenerative conditions of the CNS (Rothwell, 1999).

Concentrations of extracellular nucleotides are also known to rise significantly under inflammatory conditions in vivo. In normal tissues, extracellular nucleotide levels are low and tightly regulated (Lazarowski et al., 2000a). However, activated lymphocytes, macrophages, microglia, and platelets, as well as cells undergoing necrosis or apoptosis, release high concentrations of different nucleotide diphosphates and triphosphates into the extracellular space (Dubyak and el-Moatissim, 1993). Using chemical antagonists, we recently found that autocrine or paracrine activity of extracellular nucleotides on $\mathrm{P} 2$ receptors is required for astrocyte activation (Liu et al., 2000), and similar findings have also been reported in murine macrophages ( $\mathrm{Hu}$ et al., 1998; Sikora et al., 1999). In the present study, we tested the hypothesis that increased concentrations of extracellular nucleotides regulate 
IL-1 $\beta$ signal transduction in human astrocytes via a P2 receptormediated pathway. Our data show that extracellular nucleotides acting as ligands for $\mathrm{P} 2$ receptors modulate IL- $1 \beta$-induced transcription factor activation and differentially regulate inflammatory gene expression in primary human astrocytes; our data further indicate that different $\mathrm{P} 2$ receptor subtypes play distinct roles in determining these effects. On the basis of our results, we suggest that extracellular nucleotides coordinate inflammatory events in the CNS via $\mathrm{P} 2$ receptor-mediated signaling pathways by regulating IL- $1 \beta$-mediated signal transduction and gene expression.

\section{MATERIALS AND METHODS}

Astrocyte cultures and cytokines. Enriched human fetal brain astrocyte cultures were established from second trimester abortuses as described previously (Lee et al., 1992). All tissue collection was approved by the Institutional Clinical Review Committee. Culture purity was determined by immunostaining for glial fibrillary acidic protein (astrocytes), microtubule-associated protein-2 (neurons), and CD68 (microglia). Recombinant human IL-1 $\beta$ was a gift from the Biological Response Modifiers Program at the National Cancer Institute (Frederick, MD); the dose used $(10 \mathrm{ng} / \mathrm{ml})$ was based on dose-response studies that we have performed previously on IL-1-mediated signal transduction in human fetal astrocytes (Liu et al., 2000). It is identical to that used in studies that have examined the IL-1 signaling cascade leading to NF- $\kappa \mathrm{B}$ and AP-1 activation in several other cell types (Delhase et al., 1999; NinomiyaTsuji et al., 1999).

Treatment of cell cultures with $P 2$ receptor agonists and antagonists. 2'-3'-O-(4-benzoyl-benzoyl)-ATP (BzATP), ADP, ATP, periodateoxidized ATP (oATP), suramin, UTP (all from Sigma, St. Louis, MO), and XAMR-0721 (Calbiochem, San Diego, CA) were dissolved in DMEM and used as described at the concentrations indicated. In experiments in which $\mathrm{P} 2$ receptor antagonists were used, cells were pretreated with the antagonists for $2 \mathrm{hr}$ before IL- $1 \beta$ or P 2 agonist stimulation. In the case of the irreversible antagonist oATP, medium was changed in both oATP-treated and control cultures immediately before addition of cytokines or P2 agonists as indicated. Other (reversible) inhibitors were left in the medium during treatment of cultures.

Transient transfection and luciferase reporter assay. Cultures of primary human astrocytes were transfected using lipofectamine (Life Technologies, Grand Island, NY). Briefly, $1 \mu \mathrm{g}$ of the NF- $\kappa \mathrm{B}-$ luciferase reporter construct pIg $\kappa$-Luc (Fujita et al., 1993) or AP-1 reporter construct 6AP1-Luc (gift from Roya Khosravi-Far, Harvard Medical School) and $10 \mu \mathrm{l}$ of lipofectamine were incubated for $30 \mathrm{~min}$ in $200 \mu \mathrm{l}$ of serum- and antibiotic-free medium to form DNA-liposome complexes. Astrocytes in six-well plates ( $80 \%$ confluent) were incubated with the transfection mix for $5 \mathrm{hr}$, then transferred to medium containing 5\% FBS. Eighteen hours later, cells were treated with the indicated agents for the times shown and harvested with $300 \mu \mathrm{l}$ of reporter lysis buffer (Boehringer Mannheim, Indianapolis, IN). Lysate $(20 \mu \mathrm{l})$ was added to $100 \mu \mathrm{l}$ of luciferase substrate (Boehringer Mannheim) for $10 \mathrm{sec}$, and relative light units (RLU) were determined (Lumat LB Luminometer; Berthold Systems Inc., Aliquippa, PA). Additional experiments were performed to control for background activity of the reporter vectors. No activity was observed in cells transfected with pf-Luc (empty vector control for pIgk-Luc) and stimulated with each of the experimental conditions tested. Low-level background activity was noted in cells transfected with $\Delta 56$ fosdE-Luc (empty vector control for 6AP1-Luc), but did not reach the levels observed in control cells transfected with 6AP1-Luc. Controls for transfection efficiency were performed using pGreen Lantern (Life Technologies); they demonstrated that transfection efficiency did not differ between wells from the same cases plated at the same density, as we have also described previously (Liu et al., 2000).

Electromobility shift assay. Confluent astrocyte cultures in $100 \mathrm{~mm}$ dishes were serum-starved for $72 \mathrm{hr}$ and then treated as described in figure legends. Nuclear extracts were prepared on ice using a modified Dignam method (Akama et al., 1998), with all buffers supplemented with $1 \mathrm{~mm}$ PMSF, $1 \mathrm{~mm}$ DTT, and a mixture of protease inhibitors (Boehringer Mannheim). Cells $\left(\sim 3 \times 10^{6}\right)$ were scraped into $1.2 \mathrm{ml}$ of $1 \mathrm{~mm}$ PMSF and calcium-magnesium-free PBS and pelleted in microcentrifuge tubes. Pellets were resuspended in low salt buffer (10 mM HEPES, $\mathrm{pH} 7.9,1.5 \mathrm{~mm} \mathrm{MgCl}_{2}, 10 \mathrm{~mm} \mathrm{KCL}$ ) and allowed to sit on ice for $10 \mathrm{~min}$ before the addition of $75 \mu \mathrm{l}$ of $10 \%$ Nonidet P-40. Then, samples were vortexed $(10 \mathrm{sec})$ and centrifuged $(13,000 \mathrm{~g}, 30 \mathrm{sec})$. The nuclear pellet was resuspended in high salt buffer $(20 \mathrm{~mm}$ HEPES, pH $7.9,25 \%$ glycerol, $420 \mathrm{~mm} \mathrm{NaCl}, 1.5 \mathrm{~mm} \mathrm{MgCl}_{2}, 0.2 \mathrm{~mm}$ EDTA) and allowed to rock gently at $4^{\circ} \mathrm{C}$ for $30 \mathrm{~min}$ before centrifugation $(13,000 \mathrm{~g}, 15 \mathrm{~min})$. Supernatants were collected, and protein content was determined using the Bradford assay. Electromobility shift assay (EMSA) was performed using the Gel Shift Assay System (Promega, Madison, WI) and $\gamma_{-}{ }^{32} \mathrm{P}$ labeled oligonucleotides containing the NF- $\kappa$ B (5'-AGT TGA GGG GAC TTT CCC AGG C-3') or AP-1 (5'-CGC TTG ATG AGT CAG CCG GAA-3') consensus binding sequences. As a control, nuclear extracts $(4 \mu \mathrm{g})$ were incubated in binding buffer [4\% glycerol, $50 \mu \mathrm{g} / \mathrm{ml}$ poly(dI-dC), $1 \mathrm{~mm} \mathrm{MgCl} 2,0.5 \mathrm{~mm}$ EDTA, $50 \mathrm{~mm} \mathrm{NaCl}, 10 \mathrm{~mm}$ Tris-HCl] with 1.75 pmol of either specific or nonspecific competitor oligonucleotides for $15 \mathrm{~min}$ before addition of labeled probe. After incubation at room temperature for $20 \mathrm{~min}$, supershift antibodies $(2 \mu \mathrm{g}$; Santa Cruz Biotechnology, Santa Cruz, CA) were added to some samples for another $40 \mathrm{~min}$. Samples were separated on a $5.5 \%$ polyacrylamide $/ 5 \%$ glycerol gel in Tris-glycine buffer.

RNase protection assay. Confluent astrocyte cultures in $100 \mathrm{~mm}$ dishes were serum-starved for $72 \mathrm{hr}$ and treated as described in figure legends. Total RNA was extracted using Trizol (Life Technologies), and $10 \mu \mathrm{g}$ per sample was analyzed by RNase protection assay using a commercially available template set (BD PharMingen, San Diego, CA), according to the manufacturer's instructions. Bands obtained on autoradiography were quantitated on a Storm 860 scanner using ImageQuant software (Molecular Dynamics, Sunnyvale, CA) and compared with the housekeeping gene large ribosomal subunit L32.

Sandwich ELISA. Supernatants collected from confluent astrocyte cultures treated as above were analyzed for IL-8 and interferon-gammainducible protein of $10 \mathrm{kDa}$ (IP-10) protein concentrations. Matched capture and detection monoclonal antibodies for IP-10 and streptavidinhorseradish peroxidase conjugate were purchased from BD PharMingen. Capture antibody in PBS was used to coat 96-well plates (Maxisorp; Nalge Nunc, Rochester, NY) at room temperature overnight; then plates were washed $(0.05 \%$ Tween 20 in PBS), blocked in PBS containing $1 \%$ BSA, $5 \%$ sucrose, and $0.05 \% \mathrm{NaN}_{3}(2 \mathrm{hr})$, and washed again. Samples and recombinant standard were added and incubated for $2 \mathrm{hr}$, followed after washing by detection antibody in PBS $(2 \mathrm{hr})$, and after additional washing by streptavidin-horseradish peroxidase conjugate $(30 \mathrm{~min})$. The assay was developed using TMB peroxidase substrate (Bio-Rad, Hercules, CA), and the reaction was stopped using $0.5 \mathrm{~m}$ sulfuric acid. A commercially available sandwich ELISA (Quantikine; R\&D Systems, Minneapolis, MN) was used to measure concentrations of IL-8. Absorbance was read at $450 \mathrm{~nm}$ on a microplate reader (Bio-Rad) for both the IP-10 and IL-8 assays.

Reverse transcription-PCR and cloning. At indicated times, total RNA was isolated from confluent cultures using Trizol. RNA $(10 \mu \mathrm{g})$ was treated with DNase-1 (Promega) and subjected to phenol-chloroform extraction. First strand cDNA was prepared using oligo-dT and the SuperScript II preamplification system (Life Technologies) and amplified directly by PCR using Pfu (Stratagene, La Jolla, CA). As a control, RNA samples were also subjected to the first strand cDNA preparation protocol without reverse transcriptase. Primers were based on the reported sequences of the human $\mathrm{P} 2 \mathrm{Y}_{1}, \mathrm{P}_{2} \mathrm{Y}_{2}, \mathrm{P}_{2} \mathrm{Y}_{4}$, and $\mathrm{P} 2 \mathrm{X}_{7}$ receptors (Parr et al., 1994; Communi et al., 1995; Ayyanathan et al., 1996; Rassendren et al., 1997), and the primers for $\mathrm{P}_{2} \mathrm{Y}_{2}, \mathrm{P}_{2} \mathrm{Y}_{4}$, and $\mathrm{P} 2 \mathrm{X}_{7}$ have been published previously (Gorodeski et al., 1998; Merten et al., 1998; Wiley et al., 1998): $\mathrm{P}_{2} \mathrm{Y}_{1}$ forward, 5'-GAC TTC TTG TAC GTG CTG ACT CT-3'; and reverse, 5'-GAC CTC TTG TCA CCT GAT ACG TG-3'; P2Y 2 forward, 5'-CTC TAC TTT GTC ACC ACC AGC GCG-3'; and reverse, 5'-TTC TGC TCC TAC AGC CGA ATG TCC-3'; P2Y ${ }_{4}$ forward, 5'-ATC CTG CCA CCC TCA CTT CTC C-3'; and reverse, $5^{\prime}$-AGG CGA GAA GAC GAC TGT GC-3'; and P2X ${ }_{7}$ forward, 5'-ACT CCT AGA TCC AGG GAT AGC C-3'; and reverse, 5'-TCA CTC TTC GGA AAC TCT TTC C- $3^{\prime}$. Conditions applied for PCR were as follows: $95^{\circ}$ for $5 \mathrm{~min}$, followed by 31 cycles of $1 \min 95^{\circ} \mathrm{C}, 1 \mathrm{~min} 64.4^{\circ} \mathrm{C}\left(\mathrm{P} 2 \mathrm{Y}_{1}, \mathrm{P} 2 \mathrm{Y}_{2}, \mathrm{P} 2 \mathrm{X}_{7}\right)$ or $61.8^{\circ} \mathrm{C}$ $\left(\mathrm{P} 2 \mathrm{Y}_{4}\right)$, and $1 \mathrm{~min} 72^{\circ} \mathrm{C}$, followed by $72^{\circ} \mathrm{C}$ for $7 \mathrm{~min}$. Samples were separated by electrophoresis in ethidium bromide-impregnated $1.5 \%$ agarose gels. Identity of PCR product was confirmed by cloning and sequencing as previously reported (John et al., 1999).

Statistics. Where applicable, results are presented as mean \pm SEM. Statistical analysis was performed using ANOVA followed by Bonferroni post test, and $p<0.05$ was considered significant. 
Figure 1. IL-1 $\beta$-mediated activation of $\mathrm{NF}-\kappa \mathrm{B}$ is potentiated by extracellular ATP binding to $\mathrm{P} 2$ receptors. $A$, Astrocyte cultures were transfected transiently with a luciferase reporter construct for NF- $\kappa \mathrm{B}$ activation. Cells were treated with IL-1 $\beta$ (10 ng/ml), ATP $(100 \mu \mathrm{M})$, or both, and luciferase activity was measured in relative light units $(R L U)$ at 3 and $6 \mathrm{hr}$. Results are presented as mean \pm SEM, at least three observations per condition. Activation of NF- $\kappa$ B induced by IL- $1 \beta$ was significantly potentiated by ATP at both $3 \mathrm{hr}$ $(p<0.001$; one-way ANOVA followed by Bonferroni post test) and $6 \mathrm{hr}(p<$ $0.001)$. ATP alone induced only weak $\mathrm{NF}-\kappa \mathrm{B}$ activation. Data are representative of six separate experiments on as-

A.

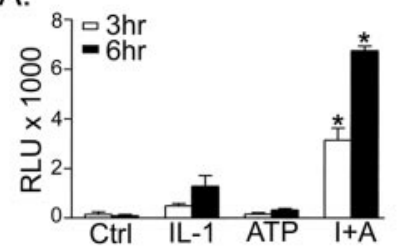

B.

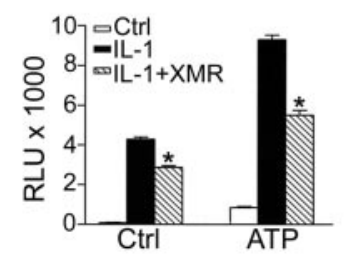

C.

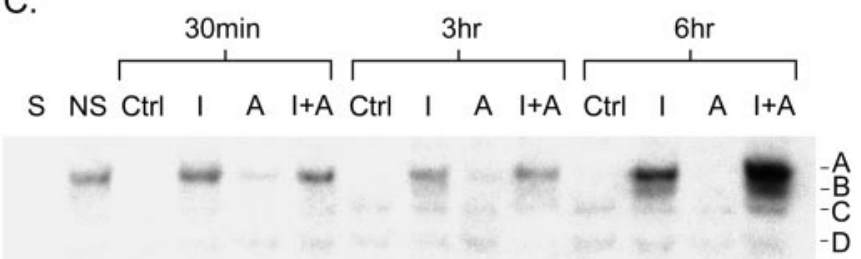

trocytes from five different brains. $B$, Cells were transfected transiently with the NF- $\kappa \mathrm{B}$ reporter, then treated as above in the presence or absence of pretreatment with XAMR-0721 $(300 \mu \mathrm{M})$, and luciferase was measured at $6 \mathrm{hr}$. P2 receptor blockade strongly downregulated NF- $\kappa \mathrm{B}$ activation induced by ATP plus IL-1 $\beta(p<0.001)$ or IL-1 $\beta$ alone $(p<0.001)$. $C$, Astrocyte cultures were treated with IL-1 $\beta$ (I lanes), ATP $(A$ lanes $)$, or both as above. Nuclei were harvested at $30 \mathrm{~min}$ and 3 and $6 \mathrm{hr}$ and subjected to EMSA with a radiolabeled oligonucleotide probe containing the NF- $\kappa \mathrm{B}$ binding site, along with specific (S lane) and nonspecific (NS lane) competitor oligonucleotides. Four shift complexes $(A-D)$ were observed. Complex A was strongly enhanced by IL-1 $\beta$, most notably at $6 \mathrm{hr}$, and also weakly by ATP at $30 \mathrm{~min}$ and $3 \mathrm{hr}$. ATP strongly potentiated the response to IL-1 $\beta$ at 6 hr. The experiment shown is representative of four experiments using astrocytes from four different brains.

\section{RESULTS}

\section{Induction of NF- $\kappa$ B transcriptional activation by IL-1 $\beta$ is potentiated by binding of extracellular ATP to P2 receptors}

Binding of IL- $1 \beta$ to the type I IL- 1 receptor leads to dosedependent activation of the transcription factors $\mathrm{NF}-\kappa \mathrm{B}$ and AP-1, inducible enhancers of multiple inflammatory genes, including chemokines, cytokines, and effector molecules. To determine the effect of extracellular ATP on IL- $1 \beta$-induced NF- $\kappa$ B activation in human fetal astrocytes, cells were transfected transiently with the NF- $\kappa \mathrm{B}$ dependent reporter $\mathrm{pIg} \kappa$-Luc, then stimulated with IL-1 $\beta$ (10 ng/ml) and different concentrations of ATP; luciferase activity was measured after 3 and $6 \mathrm{hr}$. As previously demonstrated in our laboratories (Liu et al., 2000), activation of $\mathrm{NF}-\kappa \mathrm{B}$ was induced by $10 \mathrm{ng} / \mathrm{ml} \mathrm{IL-1 \beta}$. Interestingly, ATP strongly potentiated IL- $1 \beta$-induced activation of NF$\kappa \mathrm{B}$, although ATP alone induced only low level NF- $\kappa \mathrm{B}$ activation even at a concentration of $100 \mu \mathrm{M}$ (Fig. 1A). The effects of ATP were observed after both 3 and 6 hr (Fig. 1A) and were dosedependent (1-100 $\mu \mathrm{M}$; data not shown).

To determine whether the effect of ATP on IL-1 $\beta$-induced $\mathrm{NF}-\kappa \mathrm{B}$ activation was mediated via $\mathrm{P} 2$ receptors, we pretreated astrocytes transfected with the $\mathrm{NF}-\kappa \mathrm{B}$ reporter construct with $\mathrm{P} 2$ receptor antagonists for $2 \mathrm{hr}$, and then activated them with IL-1 $\beta$ $(10 \mathrm{ng} / \mathrm{ml})$, ATP $(100 \mu \mathrm{M})$, or both for $6 \mathrm{hr}$. Pretreatment with P2 antagonists including XAMR-0721 (Fig. 1B), oxidized ATP, or suramin (data not shown) at $300 \mu \mathrm{M}$ significantly downregulated activation of NF- $\kappa$ B induced by IL- $1 \beta$, ATP, or ATP plus IL- $1 \beta$. The concentrations of antagonists that were used were based on previous findings in our laboratory and other laboratories that have shown that $\mathrm{P} 2$ receptor blockade downregulates signaling by IL- $1 \beta, \mathrm{TNF} \alpha$, and LPS in human astrocytes and mouse macrophages (Hu et al., 1998; Sikora et al., 1999; Liu et al., 2000). At these concentrations, none of the receptor antagonists had any effect on cell viability, as determined by $\mathrm{LDH}$ release or trypan blue exclusion (data not shown).

\section{Extracellular ATP potentiates IL-1 $\beta$-induced NF- $\kappa$ B nuclear translocation and DNA binding}

The effect of ATP on IL- $1 \beta$-induced NF- $\kappa$ B nuclear translocation and consensus sequence binding was examined at specific time points using an EMSA. Astrocytes were stimulated with IL-1 $\beta(10 \mathrm{ng} / \mathrm{ml})$, ATP $(100 \mu \mathrm{M})$, or both, and nuclear extracts were prepared at $30 \mathrm{~min}$ and 3 and $6 \mathrm{hr}$. In samples from untreated cells, four faint mobility shift complexes were detected (Fig. 1C). IL-1 $\beta$ treatment enhanced the shift complex labeled "A" at $30 \mathrm{~min}$ and 3 and $6 \mathrm{hr}$. ATP strongly potentiated the response to IL-1 $\beta$ at $6 \mathrm{hr}$ (Fig. $1 C$ ). ATP alone induced a low level of NF- $\kappa \mathrm{B}$ DNA binding at $30 \mathrm{~min}$ and $3 \mathrm{hr}$. All four complexes could be competed out with a $50 \mathrm{M}$ excess of NF- $\kappa \mathrm{B}-$ specific cold oligonucleotide in all samples ( $3 \mathrm{hr}$ IL- $1 \beta$-treated are illustrated; $S$ lanes) but not by a nonspecific competitor (NS lanes). Supershift experiments demonstrated that IL- $1 \beta$-induced $\mathrm{NF}-\kappa \mathrm{B}$ was a p65/p50 heterodimer and that ATP had no effect on the subunit composition (data not shown).

\section{Binding of extracellular ATP to P2 receptors induces AP-1 transcriptional activation and potentiates IL-1 $\beta$ - induced AP-1 activation}

Like NF- $\kappa$ B, AP- 1 is induced by IL- $1 \beta$ and regulates the inducible expression of multiple inflammatory genes (Davis, 2000). IL- $1 \beta$ induced AP-1 activation in these cells, as previously demonstrated in our laboratory (Liu et al., 2000). Interestingly, AP-1 activation was also induced strongly by ATP alone. The effects of IL- $1 \beta$ and ATP on AP- 1 activation were additive at both 3 and 6 hr time points (Fig. $2 A$ ). Blockade of $\mathrm{P} 2$ receptors strongly reduced AP-1 activation induced by ATP or ATP plus IL-1 $\beta$ (Fig. $2 B$ ).

An EMSA was used to examine AP-1 nuclear translocation and DNA binding. In samples from control cultures, there were two faint mobility shift complexes (Fig. $2 C$ ). Treatment of cells with IL-1 $\beta$ resulted in progressive enhancement of the upper shift complex at $30 \mathrm{~min}$ and 3 and $6 \mathrm{hr}$. Treatment with ATP also enhanced the upper shift complex but with different kinetics; the strongest enhancement was observed at $3 \mathrm{hr}$. Cotreatment with IL- $1 \beta$ and ATP led to AP-1 activation that was strongest at $6 \mathrm{hr}$. Both mobility shift complexes could be competed out with a $50 \mathrm{M}$ 
A.

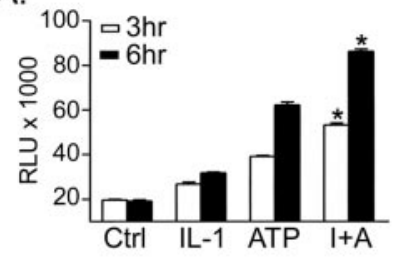

B.

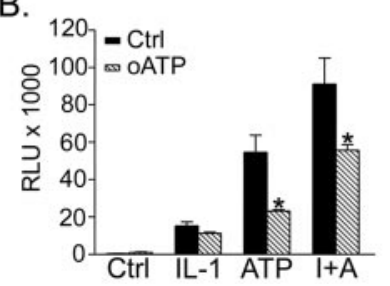

C.

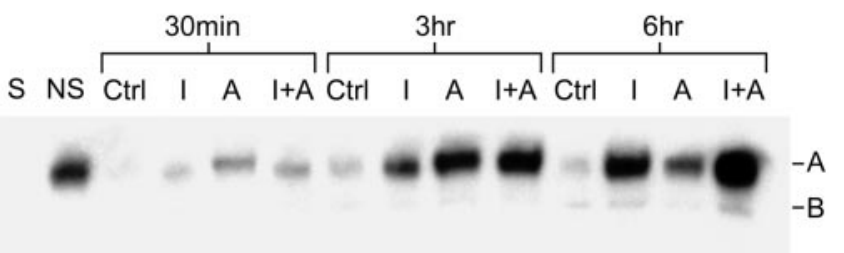

Figure 2. Extracellular ATP binding to $\mathrm{P} 2$ receptors activates AP-1 and potentiates IL- $1 \beta$-mediated AP-1 activation. $A$, Astrocyte cultures were transfected transiently with a luciferase reporter construct for AP-1 activity. Cells were treated with IL-1 $\beta$ (10 ng/ml), ATP $(100 \mu \mathrm{M})$, or both, and luciferase activity was measured at 3 and $6 \mathrm{hr}$. AP-1 activation was induced strongly by ATP and was also induced by IL- $1 \beta$. The effect of cotreatment with IL-1 $\beta$ and ATP was significantly greater than that of either alone at both $3 \mathrm{hr}(p<0.001)$ and $6 \mathrm{hr}$ $(p<0.001)$. Data are representative of nine experiments using astrocytes from eight different brains. $B$, Astrocyte cultures were transfected transiently with the AP-1 luciferase reporter construct and treated with IL- $1 \beta$, ATP, or both as above in the presence or absence of oATP $(300 \mu \mathrm{M})$; luciferase activity was measured at $6 \mathrm{hr}$. P2 receptor blockade strongly downregulated AP-1 activation induced by ATP $(p<0.01)$ or ATP plus IL-1 $\beta(p<0.01)$. $C$, Nuclei were harvested at 30 min and 3 and 6 hr from astrocyte cultures treated with IL-1 $\beta$, ATP, or both as above and subjected to EMSA with a radiolabeled oligonucleotide probe containing the AP-1 binding site. Specificity was confirmed using specific (S lane) and nonspecific (NS lane) competitor oligonucleotides. Two shift complexes $(A, B)$ were observed. IL-1 $\beta$ induced progressive enhancement of complex A. ATP also induced enhancement of this complex, but with different kinetics; the strongest response to ATP was observed at $3 \mathrm{hr}$. Cotreatment with IL- $1 \beta$ and ATP led to a response that was most pronounced at 6 hr. Data are representative of four experiments using astrocytes from four brains.

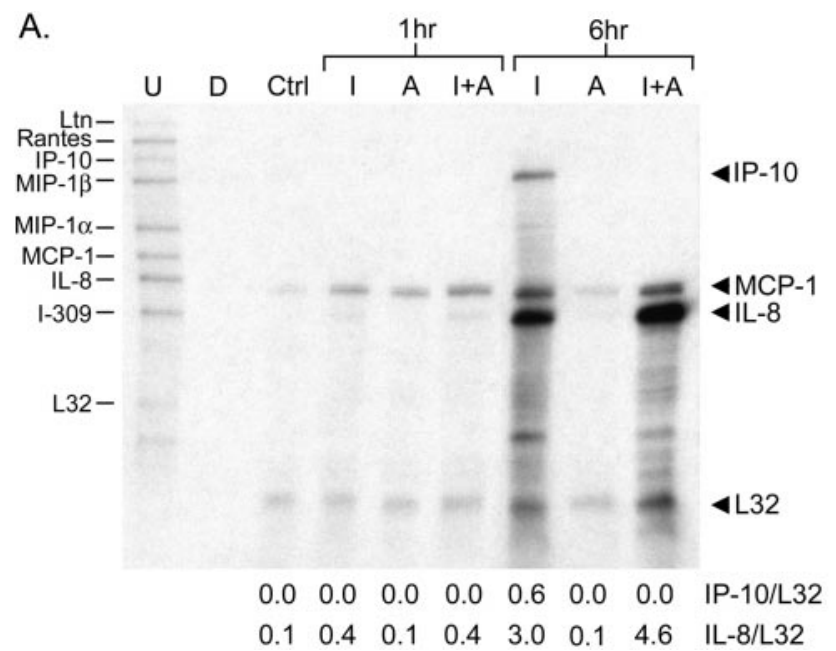

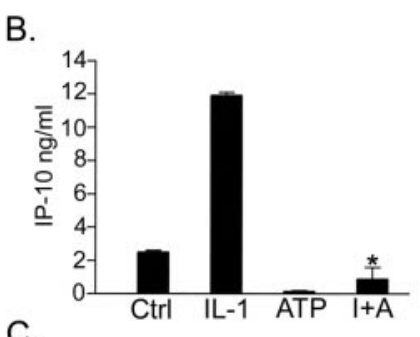

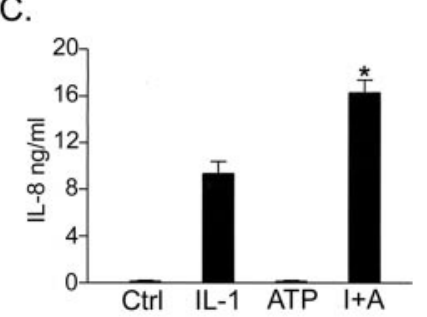

Figure 3. Extracellular ATP differentially regulates IL- $1 \beta$-induced expression of IP-10 and IL-8. $A$, RNA was extracted at 1 and $6 \mathrm{hr}$ from astrocyte cultures treated with IL-1 $\beta(10 \mathrm{ng} / \mathrm{ml})$, ATP $(100$ $\mu \mathrm{M})$, or both and subjected to RNase protection assay analysis of IP-10, IL-8, and large ribosomal subunit L32. Undigested $(U)$ and digested $(D)$ controls are shown in the first two lanes. Densitometric ratios of IP-10 and IL-8 to L32 are given beneath each lane. ATP strongly downregulated IL- $1 \beta$-induced expression of IP-10 but upregulated IL- $1 \beta$ mediated IL-8 mRNA expression. $B, C$, Supernatants were harvested from the same cultures described in $A$ and subjected to sandwich ELISA for IP-10 $(B)$ and IL-8 $(C)$. IL- $1 \beta$-induced expression of IP-10 protein was strongly downregulated by ATP $(p<0.001)$, whereas IL-

$1 \beta$-mediated IL-8 protein expression was strongly upregulated $(p<0.001)$. Data are representative of three separate experiments on astrocytes from three different brains.

excess of cold AP-1-specific oligonucleotide in all samples (3 hr IL-1 $\beta$-treated are illustrated; $S$ lanes) but not by a nonspecific oligonucleotide (NS lanes).

\section{Extracellular ATP differentially regulates IL-1 $\beta$-induced expression of $\alpha$ chemokines IP-10 and IL-8}

Previous work has shown that in human fetal astrocytes, IL-1 $\beta$ induces expression of chemokines including IL-8, IP-10, and monocyte chemotactic protein-1 (Oh et al., 1999; Hua and Lee, 2000). To determine whether the effects of ATP on IL- $1 \beta$ induced transcription factor activation were associated with changes in IL- $1 \beta$-induced inflammatory gene expression, astrocytes were treated with IL- $1 \beta$, ATP, or both, and chemokine mRNA and protein were analyzed using RNase protection assay and sandwich ELISA. Interestingly, ATP had differential effects on expression of different $\alpha$ chemokines; ATP potentiated IL- $1 \beta$ mediated induction of IL- 8 mRNA (Fig. $3 A$ ) and protein (Fig. $3 C)$ at $6 \mathrm{hr}$, but strongly downregulated IL- $1 \beta$-induced IP-10 expression at the mRNA and protein levels (Fig. $3 A, 3 B$ ). A similar pattern of IP-10 and IL-8 protein expression was observed at $24 \mathrm{hr}$ (data not shown).

\section{Primary human fetal astrocytes express the P2 receptor subtypes $\mathrm{P}_{2} \mathrm{Y}_{1}, \mathrm{P}_{2} \mathrm{Y}_{2}, \mathrm{P}_{2} \mathrm{Y}_{4}$, and $\mathrm{P}_{2} \mathrm{X}_{7}$}

Calcium imaging experiments in our laboratories have shown previously that human fetal astrocyte cultures respond to ATP via $\mathrm{P} 2$ receptors and also to the selective agonists 2-methylthio-ATP (selective for $\left.\mathrm{P} 2 \mathrm{Y}_{1}\right)$ and $\operatorname{UTP}\left(\mathrm{P} 2 \mathrm{Y}_{2}, \mathrm{P} 2 \mathrm{Y}_{4}\right)$, but not to $\alpha, \beta$,methylene-ATP (P2X receptors) (John et al., 1999). Additional imaging experiments in our laboratory using the calcium-sensitive dye fura- 2 demonstrated that these cells also respond to BzATP, a $\mathrm{P} 2 \mathrm{X}_{7}$-selective agonist, which at a concentration of $300 \mu \mathrm{M}$ elicited an increase in $\left[\mathrm{Ca}^{2+}\right]_{\mathrm{i}}$ in $>95 \%$ of astrocytes (data not shown). Similar responses to BzATP have been observed previously in other human cell types expressing the $\mathrm{P} 2 \mathrm{X}_{7}$ receptor, including retinal Müller cells and cells of the monocytemacrophage lineage (Rassendren et al., 1997; Pannicke et al., 2000). Reverse transcription (RT)-PCR using specific primers 


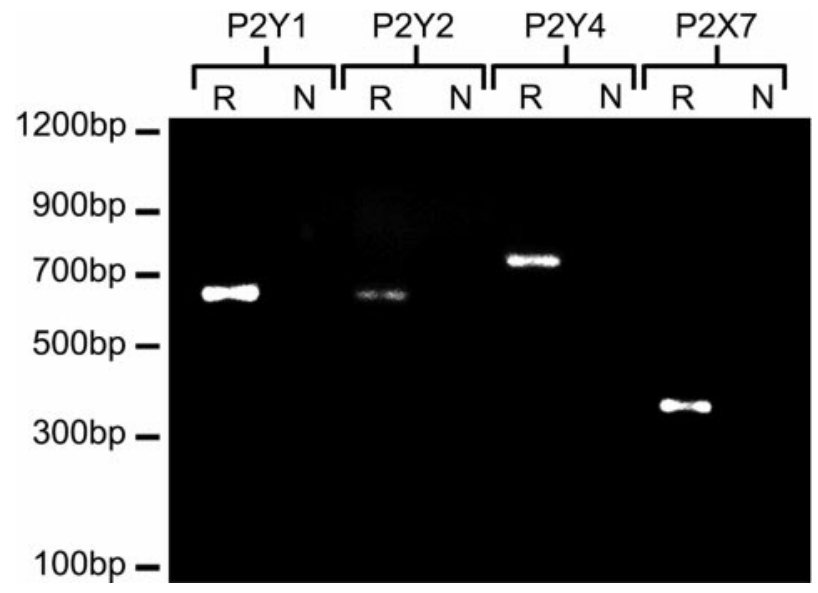

Figure 4. Human fetal astrocyte cultures express $\mathrm{P}_{2} \mathrm{Y}_{1}, \mathrm{P}_{2} \mathrm{Y}_{2}, \mathrm{P}_{2} \mathrm{Y}_{4}$, and $\mathrm{P}_{2} \mathrm{X}_{7}$. Total RNA extracted from untreated human fetal astrocyte cultures was subjected to first-strand reverse transcription followed by PCR using specific primers, and PCR product was separated on an ethidium bromide-impregnated $1.5 \%$ agarose gel. Results shown were obtained from the same batch of cDNA from astrocytes from the same brain. A single band of the expected size was detected for $\mathrm{P}_{2} \mathrm{Y}_{1}(647 \mathrm{bp}), \mathrm{P}_{2} \mathrm{Y}_{2}$ (632 bp), $\mathrm{P}_{2} \mathrm{Y}_{4}$ (765 bp), and $\mathrm{P} 2 \mathrm{X}_{7}$ (356 bp) ( $R$ lanes). Identity of the bands was confirmed by cloning and sequencing. No band was detected after RT-PCR in the absence of reverse transcriptase ( $N$ lanes). Data shown are representative of at least three separate experiments using three different brains for each receptor subtype.

confirmed expression of mRNA for $\mathrm{P}_{2} \mathrm{Y}_{1}, \mathrm{P} 2 \mathrm{Y}_{2}, \mathrm{P} 2 \mathrm{Y}_{4}$, and $\mathrm{P} 2 \mathrm{X}_{7}$ in human astrocyte cultures (Fig. 4; $R$ lanes). A single band was detected for each subtype $\left(\mathrm{P} 2 \mathrm{Y}_{1}, 647 \mathrm{bp} ; \mathrm{P} 2 \mathrm{Y}_{2}, 632 \mathrm{bp} ; \mathrm{P} 2 \mathrm{Y}_{4}\right.$, $\left.765 \mathrm{bp} ; \mathrm{P} 2 \mathrm{X}_{7}, 356 \mathrm{bp}\right)$, the identity of which was established by cloning and sequencing. Data obtained from three clones per subtype gave sequences $>97 \%$ identical to the reported Genbank sequence of that subtype $\left(\mathrm{P} 2 \mathrm{Y}_{1}, \mathrm{NM} 002563\right.$; $\mathrm{P} 2 \mathrm{Y}_{2}, \mathrm{NM} 002564$; $\left.\mathrm{P}_{2} \mathrm{Y}_{4}, \mathrm{NM} 002565 ; \mathrm{P} 2 \mathrm{X}_{7}, \mathrm{NM} 002562\right)$. No band was detected after RT-PCR in the absence of reverse transcriptase ( $N$ lanes).

\section{Agonists selective for P2 receptor subtypes expressed by human astrocytes have differential effects on IL-1 $\beta$ - induced NF- $\kappa$ B activation}

The $\mathrm{P} 2$ receptor subtypes $\mathrm{P} 2 \mathrm{Y}_{1}, \mathrm{P} 2 \mathrm{Y}_{2}$, and $\mathrm{P} 2 \mathrm{X}_{7}$ are ATPsensitive, whereas $\mathrm{P}_{2} \mathrm{Y}_{4}$ is ATP-insensitive. To determine whether the effects of ATP on IL- $1 \beta$-induced NF- $\kappa$ B and AP-1 activation were mediated via $\mathrm{P} 2 \mathrm{Y}_{1}, \mathrm{P}_{2} \mathrm{Y}_{2}$, and/or $\mathrm{P} 2 \mathrm{X}_{7}$, astrocyte cultures were treated with agonists selective for these receptor subtypes, or IL- $1 \beta$, or a selective agonist plus IL-1 $\beta$. ADP was used as a selective agonist for $\mathrm{P}_{2} \mathrm{Y}_{1}$ because it has been reported to be a full agonist at this subtype (Palmer et al., 1998), whereas 2-methylthio-ATP has been reported as only a partial agonist (Hechler et al., 1998). Results were analyzed using transcription factor-dependent luciferase reporter constructs and EMSA as described above and compared with results obtained using ATP.

In astrocytes transfected with the $\mathrm{NF}-\kappa \mathrm{B}$ reporter construct, as expected over $6 \mathrm{hr}, \mathrm{NF}-\kappa \mathrm{B}$ activation was strongly potentiated by ATP. ADP produced similar results to those obtained using ATP (Fig. 5A). BzATP (selective for $\mathrm{P}_{2} \mathrm{X}_{7}$ ) also potentiated IL-1 $\beta$ mediated NF- $\kappa \mathrm{B}$ activation, but at a lower level than was observed using ATP or ADP. In contrast, UTP (selective for $\mathrm{P}_{2} \mathrm{Y}_{2}$ and $\mathrm{P} 2 \mathrm{Y}_{4}$ ) had no effect.

An EMSA demonstrated that IL- $1 \beta$-induced NF- $\kappa$ B DNA binding was strongly potentiated by ATP and ADP (Fig. 5B). BzATP also potentiated the effect of IL- $1 \beta$, but to a lesser extent. UTP had little effect.

\section{Differential effect of P2 receptor subtype-selective agonists on AP-1 activation}

In primary astrocyte cultures transfected with the AP-1 reporter construct, interestingly, ADP alone activated AP-1 more strongly than ATP, and treatment with IL- $\beta$ and ADP together was a more potent stimulus than ADP alone (Fig. 6A). In contrast, BzATP and UTP were ineffective (Fig. 6 $A$ ). An AP-1-specific EMSA demonstrated that ADP was at least as potent as ATP in inducing AP-1 DNA binding, whereas the effects of BzATP and UTP were weaker (Fig. 6B).

\section{Selective agonists for P2 receptor subtypes regulate IL-1 $\beta$-induced expression of $\alpha$ chemokines in primary human astrocytes}

The effects of selective P2 receptor agonists on IL- $1 \beta$-induced IL-8 and IP-10 expression were compatible with their effects on NF- $\kappa$ B and AP-1 activation (Fig. 7). IL-8 expression was potentiated by ATP and ADP (Fig. 7B). BzATP also potentiated expression of IL-8 to a slightly lesser degree than ATP or ADP. UTP had no significant effect on IL-8. IP-10 expression induced by IL- $1 \beta$ was strongly downregulated by ATP, ADP, and BzATP, whereas UTP had a less potent downregulatory effect (Fig. 7A).
Figure 5. Agonists selective for $\mathrm{P} 2$ receptor subtypes expressed by astrocytes have differential effects on IL- $\beta$-mediated NF- $\kappa \mathrm{B}$ activation. Astrocyte cultures that were transiently transfected with the NF$\kappa \mathrm{B}$-specific luciferase reporter construct were treated with ATP, ADP, UTP, or BzATP $(100 \mu \mathrm{M})$ with or without IL-1 $\beta$ (10 $\mathrm{ng} / \mathrm{ml}$ ), and luciferase activity was measured at $6 \mathrm{hr}$. Results are presented as fold activation over untreated control and represent pooled data from seven experiments using astrocytes from six different brains. Each treatment was repeated on astrocytes from at least three brains, with at least three separate observations per treatment per experiment. ADP strongly potentiated IL $-1 \beta$ induced NF- $\kappa$ B activation $(p<0.001)$ in a

similar manner to ATP. BzATP also potentiated IL-1 $\beta$-mediated activation of NF- $\kappa \mathrm{B}(p<0.01)$ but was less potent than ATP or ADP. In contrast, UTP was ineffective. $B$, Nuclei harvested at $6 \mathrm{hr}$ from cultures treated as above were subjected to EMSA with radiolabeled NF- $\kappa$ B-specific oligonucleotide. IL- $1 \beta$-induced DNA binding was strongly potentiated by ATP and ADP and more weakly by BzATP. UTP had little effect. Data shown are representative of three separate experiments on cells from three different brains.
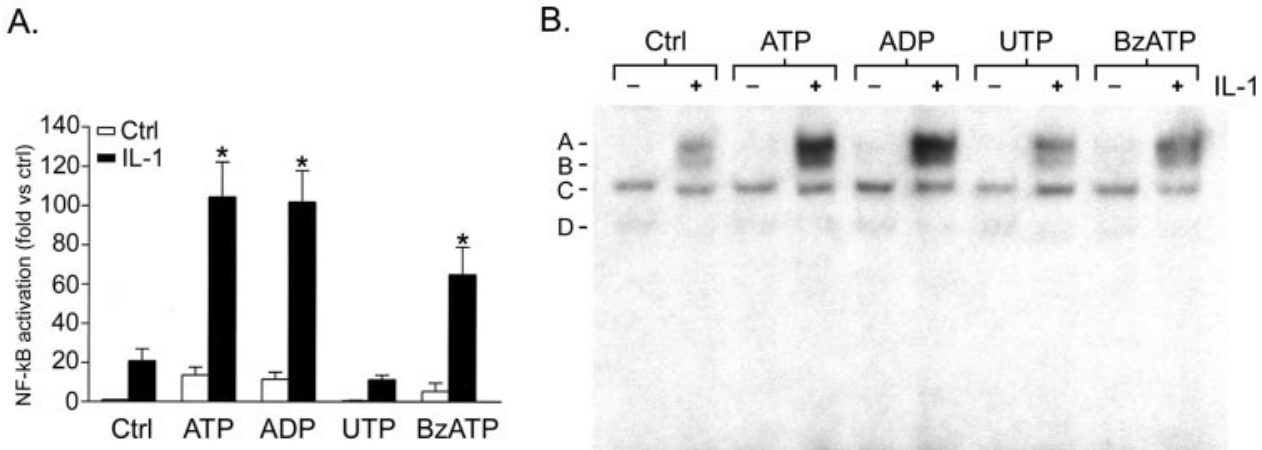

D-

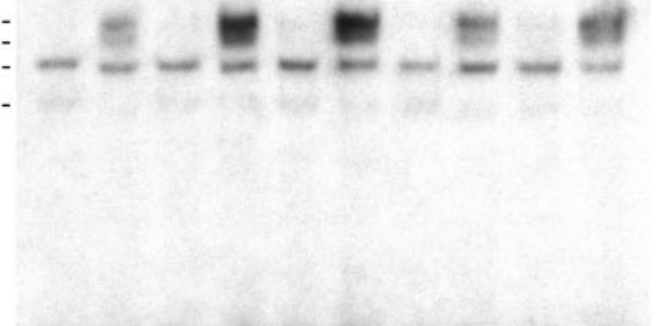

A.

Ctrl ATP ADP UTP BzATP 1

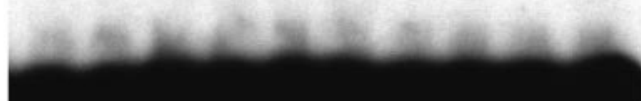
(1) 
A.

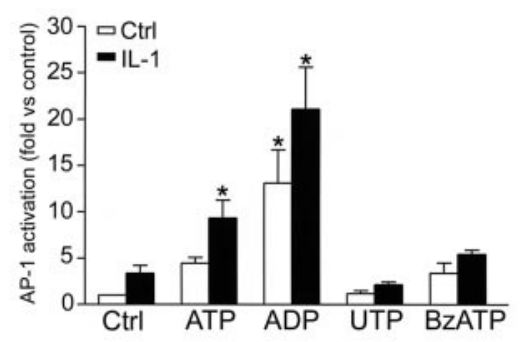

B.

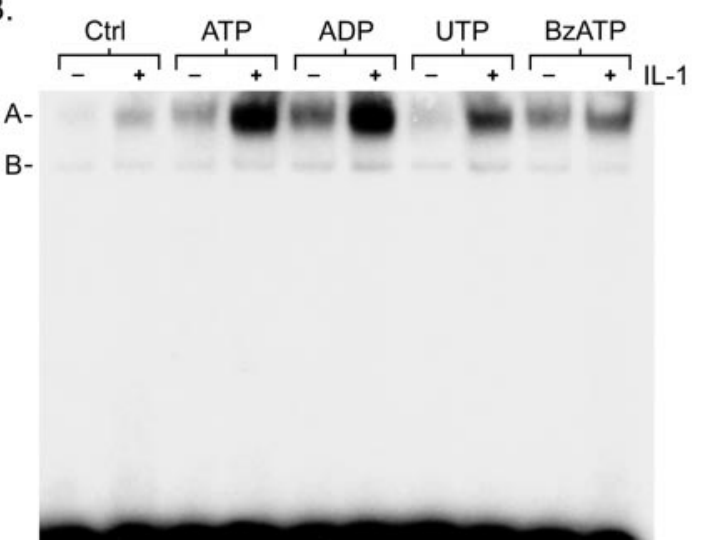

Figure 6. Differential effects of $\mathrm{P} 2$ receptor subtype-selective agonists on AP-1 activation. $A$, Astrocyte cultures transiently transfected with the AP-1-specific luciferase reporter construct were treated with ATP, ADP, UTP, or BzATP $(100 \mu \mathrm{M})$ with or without IL-1 $\beta(10 \mathrm{ng} / \mathrm{ml})$, and luciferase activity was assayed at $6 \mathrm{hr}$. ADP alone activated AP-1 more strongly than ATP $(p<0.001)$, and treatment with IL- $1 \beta$ plus ADP was a more potent stimulus than ADP alone $(p<0.001)$. In contrast, BzATP and UTP were ineffective. Data represent results pooled from eight experiments on astrocytes from seven different brains. Each treatment was repeated on astrocytes from at least three brains, with at least three observations per treatment per experiment. $B$, Cultures were treated as above, and nuclei were harvested at $6 \mathrm{hr}$ and subjected to EMSA with radiolabeled AP-1-specific oligonucleotide. ADP was at least as effective as ATP in inducing AP-1 DNA binding, whereas the effects of BzATP and UTP were weaker. Data shown are representative of three separate experiments on astrocytes from three different brains.

\section{DISCUSSION}

The studies described in this report arose from our original observation that exposure of human astrocytes to IL- $1 \beta$ leads to an alteration in the pathways used by these cells to mediate

\section{A.}

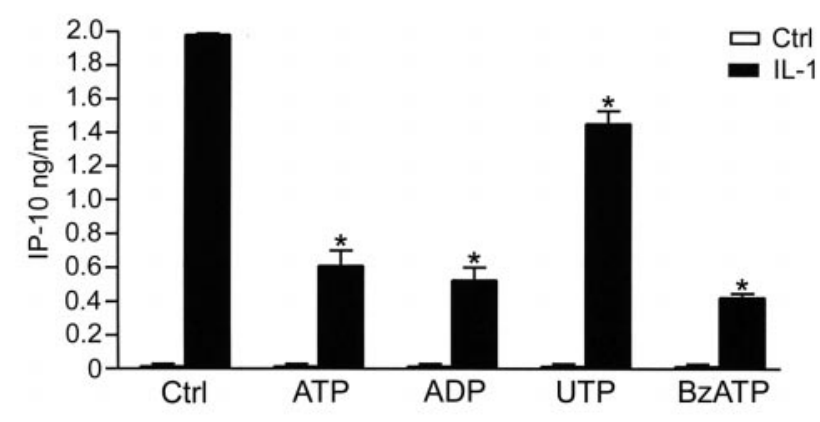

B.

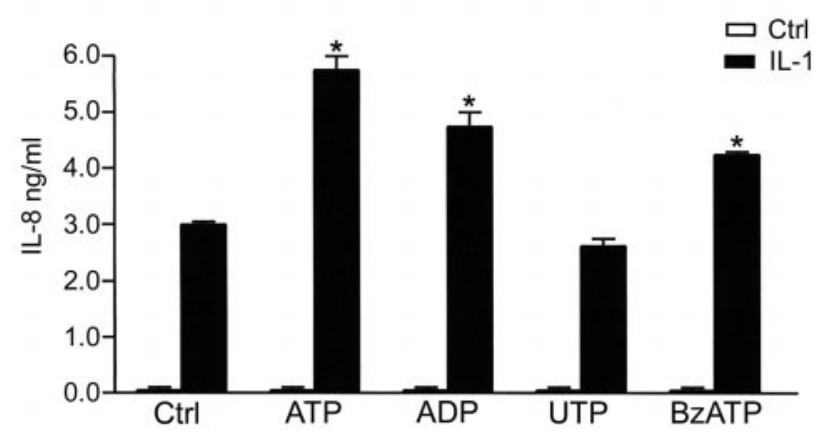

Figure 7. Selective agonists for $\mathrm{P} 2$ receptor subtypes play distinct roles in regulating IL- $1 \beta$-mediated $\alpha$ chemokine expression. Astrocyte cultures were treated with ATP, ADP, UTP, or BzATP $(100 \mu \mathrm{M})$ with or without $\mathrm{IL}-1 \beta(10 \mathrm{ng} / \mathrm{ml})$, and supernatants were harvested at $6 \mathrm{hr}$ and subjected to sandwich ELISA for both IP-10 and IL-8. $A$, IL- $1 \beta$-mediated expression of IP-10 was strongly downregulated by ATP $(p<0.001)$, ADP $(p<$ $0.001)$, and $\operatorname{BzATP}(p<0.001)$, whereas UTP had a downregulatory effect that was weaker but still significant $(p<0.001)$. $B$, Expression of IL-8 induced by IL- $1 \beta$ was strongly potentiated by ATP $(p<0.001)$ and by ADP $(p<0.001)$. BzATP also potentiated IL- $1 \beta$-mediated IL- 8 expression $(p<0.01)$ but was less potent than ATP or ADP. In contrast, UTP was ineffective. cell-cell communication, shifting the mode of intercellular calcium wave transmission from a predominantly gap junctiondependent mechanism to a $\mathrm{P} 2$ receptor-dependent mechanism (John et al., 1999). These findings supported the conclusion that extracellular nucleotide signaling through $\mathrm{P} 2$ receptors may form an important regulatory mechanism controlling astrocyte function under inflammatory conditions. To test this hypothesis with respect to the known contribution of astrocytes to immunological responses in the CNS, we showed that blockade of $\mathrm{P} 2$ receptor signaling significantly downregulated IL- $1 \beta$-induced expression of the proinflammatory genes TNF $\alpha$, IL-6, and iNOS (Liu et al., 2000). Compatible results have been reported by groups working with murine macrophages; in these cells, $\mathrm{P} 2$ receptor blockade downregulates LPS-induced iNOS expression and nitrite production (Hu et al., 1998; Sikora et al., 1999). In the present report, we have expanded on these data and now show that selective agonists for some, but not all $\mathrm{P} 2$ receptor subtypes expressed by astrocytes potentiate IL- $1 \beta$-induced activation of the transcription factors $\mathrm{NF}-\kappa \mathrm{B}$ and $\mathrm{AP}-1$ and differentially regulate expression of the chemokines IL-8 and IP-10, early response genes involved in the initiation of the inflammatory cascade.

Although nucleotides such as ATP are present in millimolar concentrations in the cytosol of all cell types, in resting tissues extracellular nucleotide concentrations are maintained at low levels. There is minimal movement of nucleotides across lipid bilayers, and ectonucleotidases rapidly hydrolyze nucleotides in the extracellular space (Lazarowski et al., 2000a). However, in areas of inflammation, extracellular nucleotide concentrations rise significantly from sources that include the cytosol of ruptured, dead, or dying cells (Dubyak and el-Moatissim, 1993), degranulating platelets (Beigi et al., 1999), and activated T lymphocytes (Filippini et al., 1990), macrophages (Sikora et al., 1999), and microglia (Ferrari et al., 1997a). In our experiments ATP strongly potentiated IL- $1 \beta$-mediated NF- $\kappa$ B activation in astrocytes but had little effect on NF- $\kappa$ B in the absence of IL- $1 \beta$. In contrast, ATP alone was sufficient to induce AP-1 activation, whereas ATP and IL- $1 \beta$ together were approximately additive. The effects of ATP were dose-dependent, observed at concentrations as low as $1 \mu \mathrm{M}(3000-5000$ times lower than the concentration of ATP found in cell cytoplasm), and were blocked by P2 receptor antagonists. Most cell types express multiple $\mathrm{P} 2$ receptor subtypes; using RT-PCR, we detected the presence of $\mathrm{P}_{2} \mathrm{Y}_{1}$, 
$\mathrm{P}_{2} \mathrm{Y}_{2}, \mathrm{P}_{2} \mathrm{Y}_{4}$, and $\mathrm{P} 2 \mathrm{X}_{7}$ in human fetal astrocytes in culture. This pattern of $\mathrm{P} 2 \mathrm{Y}$ expression is consistent with what has been detected in rat cortical and cerebellar astrocytes (Jimenez et al., 2000; Lenz et al., 2000), and signaling through these receptors has also been implicated in regulation of the cytoskeletal network, cell-cycle progression, and release of prostaglandins (Stella et al., 1997; Brambilla et al., 1999; Neary et al., 1999). ATP-induced formation of AP-1 complexes has also been reported in rat cortical astrocytes (Neary et al., 1996). Using a panel of subtypeselective $\mathrm{P} 2$ receptor agonists, we found that ADP (selective for $\mathrm{P} 2 \mathrm{Y}_{1}$ ) produced results similar to or greater than those obtained using ATP, whereas BzATP (selective for $\mathrm{P}_{2} \mathrm{X}_{7}$ ) was less potent than ATP, and UTP $\left(\mathrm{P}_{2} \mathrm{Y}_{2}, \mathrm{P}_{2} \mathrm{Y}_{4}\right)$ was ineffective. These data strongly implicate a role for the $\mathrm{P} 2 \mathrm{Y}_{1}$ receptor in mediating the effects of ATP on IL- $1 \beta$-induced NF- $\kappa$ B and AP- 1 activation, and this would be consistent with the dominant effect of this receptor in mediating increases in $\left[\mathrm{Ca}^{2+}\right]_{\mathrm{i}}$ in astrocyte cultures (John et al., 1999; Fam et al., 2000). In this context, we have also noted with interest a recent report that ADP and UDP accumulate in cell culture medium in addition to ATP and UTP (Lazarowski et al., 2000a), and that the extracellular concentration of ADP may rise to a level up to five times greater than that of ATP (Lazarowski et al., 2000b).

Our results also suggest a stimulatory, albeit more minor, role for the $\mathrm{P} 2 \mathrm{X}_{7}$ receptor. This receptor, which is an atypical member of the ionotropic $\mathrm{P} 2 \mathrm{X}$ receptor family, has been investigated most extensively in cells of the monocyte-macrophage lineage (Surprenant et al., 1996). In rat macrophages and microglia, $\mathrm{P}_{2} \mathrm{X}_{7}$ has been implicated in the formation of a large transmembrane pore that allows the bidirectional passage of molecules up to $900 \mathrm{Da}$. Activation of $\mathrm{P}_{2} \mathrm{X}_{7}$ with high dose ATP (1-3 mM) has also been implicated in the activation of NF- $\kappa \mathrm{B}$ and SAPK/JNK and subsequent cell death (Ferrari et al., 1997a; Humphreys et al., 2000), as well as in the release of cytokines such as IL-1 (Ferrari et al., 1997b; Solle et al., 2000). However, the rat and human ${\mathrm{P} 2 \mathrm{X}_{7}}$ receptors have been reported to differ in their properties, particularly with regard to pore formation (Rassendren et al., 1997). The membrane permeability to large cations has been shown to be much lower in the human than in the rat receptor, and ATP-triggered dye uptake in cells transfected with the human receptor or in human macrophages is only $20 \%$ of that observed in cells transfected with the rat receptor. Similar results have recently been reported for human retinal Müller cells, which share properties in common with astrocytes and have been shown to express $\mathrm{P} 2 \mathrm{X}_{7}$ by RT-PCR, immunocytochemistry, and electrophysiology but do not form a pore in response to BzATP (Pannicke et al., 2000). It has been suggested that the species-specific differences observed in the properties of $\mathrm{P} 2 \mathrm{X}_{7}$ may reflect differences in the $\mathrm{C}$-terminal domain of the human versus the rat receptor (Rassendren et al., 1997). Our data are compatible with these findings; using a Lucifer yellow permeability assay we have not observed dye uptake in human fetal astrocyte cultures treated with millimolar concentrations of ATP, despite obtaining a clear RT-PCR signal for $\mathrm{P}_{2} \mathrm{X}_{7}$ as well as BzATP-induced transcription factor activation and calcium responses.

As a functional readout for nucleotide effects on astrocyte immune function, we examined the expression of the $\alpha$ chemokines IL- 8 and IP-10 because these are early response genes associated with inflammation, and our results clearly showed that extracellular nucleotides differentially regulate IL- $1 \beta$-induced expression of these two chemokines within the same time frame. That both fetal and adult human astrocytes can be activated by
IL-1 $\beta$ to express IL- 8 and IP-10 has been well established (Oh et al., 1999; Hua and Lee, 2000). IL-8 is an ELR-positive (i.e., Glu-Leu-Arg motif-containing) $\alpha$ chemokine that is principally recognized for its role as a chemotactic factor for neutrophils (Yasumoto et al., 1992), and levels of IL-8 rise dramatically in the CSF of patients with bacterial meningitis (Spanaus et al., 1997), as well as after brain injury, ischemia, and stroke (Tarkowski et al., 1997; Whalen et al., 2000). IL-8 may also play other roles in the CNS because it has been shown to provide trophic support for specific neuronal populations against a variety of toxic insults (Bruno et al., 2000). Conversely, IP-10 is an ELR-negative (i.e., contains no Glu-Leu-Arg motif) $\alpha$ chemokine with known chemotactic effects on $\mathrm{T}$ cells and monocytes, as well as antiviral, anti-angiogenic, and anti-tumor properties (Luster and Leder, 1993; Angiolillo et al., 1995; Ben-Baruch et al., 1995). It is expressed in astrocytes in a number of different inflammatory, infectious, and degenerative conditions of the CNS (Ransohoff et al., 1993; Asensio and Campbell, 1999). The promoter regions for both of these chemokines contain several transcription regulatory elements, but analysis of the IL- 8 promoter has shown that expression requires the activity of a combination of either NF- $\kappa \mathrm{B}$ and AP-1 or NF- $\kappa$ B and NF-IL-6 (Mahe et al., 1991; Yasumoto et al., 1992). Maximal IP-10 expression also requires cooperation between two sites, with strong promoter activity involving both an interferon-stimulated response element and an NF- $\kappa \mathrm{B}$ site that binds a p65 homodimer (Majumder et al., 1998). The fact that activation of astrocytes with nucleotides in the presence of IL-1 $\beta$ led to the differential regulation of IL- $1 \beta$-induced IL- 8 and IP-10 expression was unexpected, and at the present time the mechanism for this remains unclear. However, the results of the current study demonstrate that the effects of extracellular nucleotides on IL-1 $\beta$-mediated inflammatory gene expression are more complex than a general upregulation or downregulation. Expression of some genes is potentiated, whereas that of others is downregulated, and the overall effect on the inflammatory cascade may be more subtle than previously realized.

In summary, our results show that IL- $1 \beta$-induced astrocyte activation is regulated by extracellular nucleotide signaling through $\mathrm{P} 2$ receptors and that these effects are dependent on the concentration and composition of extracellular nucleotides and on the complement of receptor subtypes expressed by the cell. Our findings are compatible with the hypothesis that nucleotides released under inflammatory conditions activate autocrine or paracrine signaling pathways, permitting modulation of the inflammation that precipitated the nucleotide release (Burnstock, 1976; Dubyak, 2000). We suggest that the P2 receptor system constitutes a mechanism whereby activation of the proinflammatory signaling cascade can be coordinated with information from the extracellular environment.

\section{REFERENCES}

Akama KT, Albanese C, Pestell RG, Van Eldik LJ (1998) Amyloid beta-peptide stimulates nitric oxide production in astrocytes through an NFkappaB-dependent mechanism. Proc Natl Acad Sci USA 95:5795-5800.

Angiolillo AL, Sgadari C, Taub DD, Liao F, Farber JM, Maheshwari S, Kleinman HK, Reaman GH, Tosato G (1995) Human interferoninducible protein 10 is a potent inhibitor of angiogenesis in vivo. J Exp Med 182:155-162.

Asensio VC, Campbell IL (1999) Chemokines in the CNS: plurifunctional mediators in diverse states. Trends Neurosci 22:504-512.

Ayyanathan K, Webbs TE, Sandhu AK, Athwal RS, Barnard EA, Kunapuli SP (1996) Cloning and chromosomal localization of the human P2Y1 purinoceptor. Biochem Biophys Res Commun 218:783-788.

Beigi R, Kobatake E, Aizawa M, Dubyak GR (1999) Detection of local 
ATP release from activated platelets using cell surface-attached firefly luciferase. Am J Physiol 276:C267-C278.

Ben-Baruch A, Michiel DF, Oppenheim JJ (1995) Signals and receptors involved in recruitment of inflammatory cells. $\mathrm{J}$ Biol Chem 270:11703-11706.

Benveniste EN, Kwon J, Chung WJ, Sampson J, Pandya K, Tang LP (1994) Differential modulation of astrocyte cytokine gene expression by TGF-beta. J Immunol [Erratum (1995) 154:1521] 153:5210-5221.

Brambilla R, Burnstock G, Bonazzi A, Ceruti S, Cattabeni F, Abbracchio MP (1999) Cyclo-oxygenase-2 mediates P2Y receptor-induced reactive astrogliosis. Br J Pharmacol 126:563-567.

Breder CD, Dinarello CA, Saper CB (1988) Interleukin-1 immunoreactive innervation of the human hypothalamus. Science 240:321-324.

Brosnan CF, Lee SC (1997) Molecular biology of glia: astrocytes. In: Molecular biology of multiple sclerosis (Russell WC, ed), pp 71-96. London: Wiley.

Bruno V, Copani A, Besong G, Scoto G, Nicoletti F (2000) Neuroprotective activity of chemokines against N-methyl-D-aspartate or betaamyloid-induced toxicity in culture. Eur J Pharmacol 399:117-121.

Burnstock G (1976) Purinergic receptors. J Theor Biol 62:491-503.

Communi D, Pirotton S, Parmentier M, Boeynaems J-M (1995) Cloning and functional expression of a human uridine nucleotide receptor. J Biol Chem 270:30849-30852.

Davis RJ (2000) Signal transduction by the JNK group of MAP kinases. Cell 103:239-252.

Delhase M, Hayakawa M, Chen Y, Karin M (1999) Positive and negative regulation of IkappaB kinase activity through IKKbeta subunit phosphorylation. Science 284:309-313.

Dubyak GR (2000) Purinergic signaling at immunological synapses. J Auton Nerv Syst 81:64-68.

Dubyak GR, el-Moatassim C (1993) Signal transduction via P2purinergic receptors for extracellular ATP and other nucleotides. Am J Physiol 265:C577-C606.

Fam SR, Gallagher CJ, Salter MW (2000) P2Y(1) purinoceptormediated $\mathrm{Ca}(2+)$ signaling and $\mathrm{Ca}(2+)$ wave propagation in dorsal spinal cord astrocytes. J Neurosci 20:2800-2808.

Ferrari D, Wesselborg S, Bauer MKA, Schulze-Osthoff K (1997a) Extracellular ATP activates transcription factor NF-kappaB through the P2Z purinoreceptor by selectively targeting NF-kappaB p65. J Cell Biol 139:1635-1643.

Ferrari D, Chiozzi P, Falzoni S, Hanau S, Di Virgilio F (1997b) Purinergic modulation of interleukin-1 beta release from microglial cells stimulated with bacterial endotoxin. J Exp Med 185:579-582.

Filippini A, Taffs RE, Sitkovsky MV (1990) Extracellular ATP in T-lymphocyte activation: possible role in effector functions. Proc Natl Acad Sci USA 87:8267-8271.

Fujita T, Nolan GP, Liou HC, Scott ML, Baltimore D (1993) The candidate proto-oncogene bcl-3 encodes a transcriptional coactivator that activates through NF-kappa B p50 homodimers. Genes Dev 7:1354-1363.

Gorodeski GI, Burfeind P, Gan SU, Pal D, Abdul-Karim FW (1998) Regulation by retinoids of $\mathrm{P} 2 \mathrm{Y} 2$ nucleotide receptor mRNA in human uterine cervical cells. Am J Physiol 275:C758-C765.

Guthrie PB, Knappenberger J, Segal M, Bennett MVL, Charles AC, Kater SB (1999) ATP released from astrocytes mediates glial calcium waves. J Neurosci 19:520-528.

Hechler B, Vigne P, Leon C, Breittmayer JP, Gachet C, Frelin C (1998) ATP derivatives are antagonists of the P2Y1 receptor: similarities to the platelet ADP receptor. Mol Pharmacol 53:727-733.

$\mathrm{Hu}$ Y, Fisette PL, Denlinger LC, Guadarrama AG, Sommer JA, Proctor RA, Bertics PJ (1998) Purinergic receptor modulation of lipopolysaccharide signaling and inducible nitric-oxide synthase expression in RAW 264.7 macrophages. J Biol Chem 273:27170-27175.

Hua LL, Lee SC (2000) Distinct patterns of stimulus-inducible chemokine mRNA accumulation in human fetal astrocytes and microglia. Glia 30:74-81.

Humphreys BD, Rice J, Kertesy SB, Dubyak GR (2000) Stress-activated protein kinase/JNK activation and apoptotic induction by the macrophage P2X7 nucleotide receptor. J Biol Chem 275:26792-26798.

Jimenez AI, Castro E, Communi D, Boeynaems JM, Delicado EG, Miras-Portugal MT (2000) Coexpression of several types of metabotropic nucleotide receptors in single cerebellar astrocytes. J Neurochem 75:2071-2079.

John GR, Scemes E, Suadicani SO, Liu JSH, Charles PC, Lee SC, Spray DC, Brosnan CF (1999) IL-1 $\beta$ differentially regulates calcium wave propagation between primary human fetal astrocytes via pathways involving P2 receptors and gap junction channels. Proc Natl Acad Sci USA 96:11613-11618.

Karin M, Delhase M (2000) The I kappa B kinase (IKK) and NF-kappa B: key elements of proinflammatory signalling. Semin Immunol 12:85-98.

Lazarowski ER, Boucher RC, Harden TK (2000a) Constitutive release of ATP and evidence for major contribution of ecto-nucleotide pyrophosphatase and nucleoside diphosphokinase to extracellular nucleotide concentrations. J Biol Chem 275:31061-31068.
Lazarowski ER, Boucher RC, Harden TK (2000b) Constitutive release and extracellular interconversion of nucleotides. In: Ecto-ATPases and related ectonucleotidases (Vanduffel L, Lemmens R, eds), pp 283-294. Maastricht, the Netherlands: Shaker.

Lee SC, Liu W, Brosnan CF, Dickson DW (1992) Characterization of primary human fetal dissociated central nervous system cultures with an emphasis on microglia. Lab Invest 67:465-475.

Lee SC, Liu W, Dickson DW, Brosnan CF, Berman JW (1993) Cytokine production by human fetal microglia and astrocytes. Differential induction by lipopolysaccharide and IL-1 beta. J Immunol 150:2659-2667.

Lenz G, Gottfried C, Luo Z, Avruch J, Rodnight R, Nie WJ, Kang Y, Neary JT (2000) P(2Y) purinoceptor subtypes recruit different mek activators in astrocytes. Br J Pharmacol 129:927-936.

Liu JSH, John GR, Sikora A, Lee SC, Brosnan CF (2000) Modulation of interleukin- $1 \beta$ and tumor necrosis factor $\alpha$ signaling by $\mathrm{P} 2$ purinergic receptors in human fetal astrocytes. J Neurosci 20:5292-5299.

Luster AD, Leder P (1993) IP-10, a -C-X-C- chemokine, elicits a potent thymus-dependent antitumor response in vivo. J Exp Med 178:1057-1065.

Mahe Y, Mukaida N, Kuno K, Akiyama M, Ikeda N, Matsushima K, Murakami S (1991) Hepatitis B virus X protein transactivates human interleukin-8 gene through acting on nuclear factor $\mathrm{kB}$ and CCAAT/ enhancer-binding protein-like cis-elements. J Biol Chem 266:13759-13763.

Majumder S, Zhou LZ, Chaturvedi P, Babcock G, Aras S, Ransohoff RM (1998) Regulation of human IP-10 gene expression in astrocytoma cells by inflammatory cytokines. J Neurosci Res 54:169-180.

Merten MD, Saleh A, Kammouni W, Marchand S, Figarella C (1998) Characterization of two distinct P2Y receptors in human tracheal gland cells. Eur J Biochem 251:19-24.

Neary JT, Zhu Q, Kang Y, Dash PK (1996) Extracellular ATP induces formation of AP-1 complexes in astrocytes via P2 purinoceptors. NeuroReport 7:2893-2896.

Neary JT, Kang Y, Bu Y, Yu E, Akong K, Peters CM (1999) Mitogenic signaling by ATP/P2Y purinergic receptors in astrocytes: involvement of a calcium-independent protein kinase $\mathrm{C}$, extracellular signalregulated protein kinase pathway distinct from the phosphatidylinositol-specific phospholipase C/calcium pathway. J Neurosci 19:4211-4220.

Ninomiya-Tsuji J, Kishimoto K, Hiyama A, Inoue J, Cao Z, Matsumoto K (1999) The kinase TAK1 can activate the NIK-I kappaB as well as the MAP kinase cascade in the IL-1 signalling pathway. Nature 398:252-256.

Norenberg MD (1997) Astrocytes. In: Immunology of the nervous system (Keane RW, Hickey WF, eds), pp 173-199. New York: Oxford UP.

Oh JW, Schwiebert LM, Benveniste EN (1999) Cytokine regulation of $\mathrm{CC}$ and $\mathrm{CXC}$ chemokine expression by human astrocytes. J Neurovirol 5:82-94.

Palmer RK, Boyer JL, Schachter JB, Nicholas RA, Harden TK (1998) Agonist action of adenosine triphosphates at the human $\mathrm{P} 2 \mathrm{Y} 1$ receptor. Mol Pharmacol 54:1118-1123.

Pannicke T, Fischer W, Biedermann B, Schadlich H, Grosche J, Faude F, Wiedemann P, Allgaier C, Illes P, Burnstock G, Reichenbach A (2000) $\mathrm{P} 2 \mathrm{X} 7$ receptors in Muller glial cells from the human retina. J Neurosci 20:5965-5972.

Parr CE, Sullivan DM, Paradiso AM, Lazarowski ER, Burch LH, Olsen JC, Erb L, Weisman GA, Boucher RC, Turner JT (1994) Cloning and expression of a human $\mathrm{P}_{2 \mathrm{U}}$ nucleotide receptor, a target for cystic fibrosis pharmacotherapy. Proc Natl Acad Sci USA [Erratum (1994) 91:13067] 91:3275-3279.

Ransohoff RM, Hamilton TA, Tani M, Stoler MH, Shick HE, Major JA, Estes ML, Thomas DM, Tuohy VK (1993) Astrocyte expression of mRNA encoding cytokines IP-10 and JE/MCP-1 in experimental autoimmune encephalomyelitis. FASEB J 7:592-600.

Ransom BR, Sontheimer H (1992) The neurophysiology of glial cells. $\mathrm{J}$ Clin Neurophysiol 9:224-251.

Rassendren F, Buell GN, Virginio C, Collo G, North RA, Surprenant A

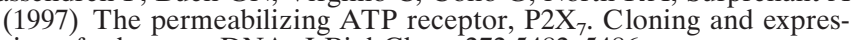
sion of a human cDNA. J Biol Chem 272:5482-5486.

Rothwell NJ (1999) Annual review prize lecture cytokines-killers in the brain? J Physiol (Lond) 514:3-17.

Scemes E, Suadicani SO, Spray DC (2000) Intercellular communication in spinal cord astrocytes: fine tuning between gap junctions and P2 nucleotide receptors in calcium wave propagation. $\mathrm{J}$ Neurosci 20:1435-1445.

Sikora A, Liu J, Brosnan C, Buell G, Chessel I, Bloom BR (1999) Cutting edge: purinergic signaling regulates radical-mediated bacterial killing mechanisms in macrophages through a P2X7-independent mechanism. J Immunol 163:558-561.

Solle M, Labasi J, Perregaux DG, Stam E, Petrushova N, Koller BH, Griffiths RJ, Gabel CA (2001) Altered cytokine production in mice lacking P2X(7) receptors. J Biol Chem 276:125-132.

Spanaus KS, Nadal D, Pfister HW, Seebach J, Widmer U, Frei K, Gloor S, Fontana A (1997) C-X-C and C-C chemokines are expressed in the cerebrospinal fluid in bacterial meningitis and mediate chemotactic 
activity on peripheral blood-derived polymorphonuclear and mononuclear cells in vitro. J Immunol 158:1956-1964.

Stella N, Estelles A, Siciliano J, Tence M, Desagher S, Piomelli D, Glowinski J, Premont J (1997) Interleukin-1 enhances the ATPevoked release of arachidonic acid from mouse astrocytes. J Neurosci 17:2939-2946.

Surprenant A, Rassendren F, Kawashima E, North RA, Buell G (1996) The cytolytic P2Z receptor for extracellular ATP identified as a P2X receptor (P2X7). Science 272:735-738.

Tarkowski E, Rosengren L, Blomstrand C, Wikkelso C, Jensen C, Ekholm S, Tarkowski A (1997) Intrathecal release of pro- and anti-inflammatory cytokines during stroke. Clin Exp Immunol 110:492-499.
Whalen MJ, Carlos TM, Kochanek PM, Wisniewski SR, Bell MJ, Clark RS, DeKosky ST, Marion DW, Adelson PD (2000) Interleukin-8 is increased in cerebrospinal fluid of children with severe head injury. Crit Care Med 28:929-934.

Wiley JS, Gargett CE, Zhang W, Snook MB, Jamieson GP (1998) Partial agonists and antagonists reveal a second permeability state of human lymphocyte P2Z/P2X7 channel. Am J Physiol 275:C1224-C1231.

Yasumoto K, Okamoto S, Mukaida N, Murakami S, Mai M, Matsushima K (1992) Tumor necrosis factor alpha and interferon gamma synergistically induce interleukin 8 production in a human gastric cancer cell line through acting concurrently on AP-1 and NF-kB-like binding sites of the interleukin 8 gene. J Biol Chem 267:22506-22511. 